\title{
Corrosion Behaviour of Aluminium in the Presence of an Aqueous Extract of Hibiscus Rosa-sinensis
}

\author{
S. Rajendran, ${ }^{1, *}$ J. Jeyasundari, ${ }^{1}$ P. Usha, ${ }^{1}$ J. A. Selvi, ${ }^{1}$ \\ B. Narayanasamy, ${ }^{2}$ A. P. P. Regis, ${ }^{3}$ P. Rengan $^{4}$ \\ ${ }^{1}$ Corrosion Research Centre, Department of Chemistry, GTN Arts College, \\ Dindigul-624005, India \\ ${ }^{2}$ Department of Chemistry, Thiagarajar College of Engineering, Madurai, India \\ ${ }^{3}$ Department of Chemistry,, St. Joseph's College, Trichy, India \\ ${ }^{4}$ Department of Chemistry, Yadava College (Co-Education), Madurai, India
}

Received 9 October 2008; accepted 16 February 2009

\begin{abstract}
The inhibition efficiency (IE) of an aqueous extract of Hibiscus rosa-sinensis (white) in controlling corrosion of aluminium at $\mathrm{pH} 12$ has been evaluated by weight loss method in the absence and presence of $\mathrm{Zn}^{2+}$. The formulation consisting of $8 \mathrm{~mL}$ flower extract (FE) and $50 \mathrm{ppm}$ of $\mathrm{Zn}^{2+}$ had $98 \%$ inhibition efficiency. Polarization study revealed that this formulation functioned as cathodic inhibitor. AC impedance spectra revealed the presence of a protective film formed on the metal surface. FTIR spectra revealed that the protective film consisted of a complex formed between the active principle of the flower extract and $\mathrm{Al}^{3+}$.
\end{abstract}

Keywords: corrosion inhibition, aluminium, Hibiscus Rosa-sinensis, plant extract, environmental friendly inhibitor.

\section{Introduction}

Aluminium and its alloys are very good corrosion resistant materials in neutral aqueous solution, due to the formation of passive film. It is well known that pitting corrosion occurs on metals covered with passive films. The $\mathrm{Cl}^{-}$ions cause the passive film to break down at certain weak spots on the metal surface. During pitting corrosion, large parts of the metal surface are covered with a protective film and are in the passive state, while other small parts of the surface are in the active state.

\footnotetext{
* Corresponding author. E-mail address: srmjoany@ sify.com
} 
Corrosion behaviour of aluminium in various mediums has been studied. Several inhibitors have been used to control corrosion of aluminium. To prevent the corrosion of aluminium in acid medium, inhibitors such as imidazoline derivatives [1], Capparis decidua [2], polyethylene glycol and polyvinyl alcohol [3], delonix regia extract [4] and Sansevieria trifasciata extract [5], have been used. In alkaline medium, polyvinyl alcohol [6], gongronema latifolium extract [7], bismark brown dye [8], methyl orange [9] and onion extract [10] have been used as corrosion inhibitors to prevent corrosion of aluminium.

Corrosion inhibition of aluminium using super hydrophobic films [11], structure and stability of adhesion promoting aminopropyl phosphonate layers at polymer/aluminium oxide interfaces [12], microbially influenced corrosion of zinc and aluminium [13], corrosion inhibition of aluminium by rare earth chlorides [14], effects of inhibitors on corrosion behaviour of dissimilar aluminium alloy friction stir weld [15], a high throughput assessment of aluminium alloy corrosion using fluorometric methods [16], surface modification for aluminum pigment inhibition [17] and filiform on 6000 series aluminium [18], have been investigated. Because of the voice raised by environmental scientists, several corrosion researchers have started using environmental friendly natural products as corrosion inhibitors [19-22]. Water extracts from leaves of date palm, phoenix dactylifera, henna, Lawsonia inermis, and corn, Zea mays, were tested as corrosion inhibitors for steel, aluminium, copper and brass in acid chloride and sodium hydroxide solutions, using weight loss, solution analysis and potential measurements [23]. Priya et al. have studied the corrosion behaviour of aluminium in rain water containing garlic extract [24]. Jain et al. have investigated the electrochemical behaviour of aluminium in acidic media. The inhibitive action of the acid extracts of seeds, leaves and bank from the ficus virens plant towards hydrochloric and sulphuric acid corrosion of aluminium has been tested using mass loss and thermometric techniques. It was found that the extract acted as a good corrosion inhibitor for aluminium corrosion in all concentration of hydrochloric and sulphuric acid solutions [25]. Anuradha et al. have investigated corrosion inhibition of carbon steel in low chloride media by an aqueous extract of Hibiscus rosa-sinensis Linn. The inhibition efficiency has been evaluated by weight loss method. Various techniques such as polarization and AC impedance spectra have been used. The protective film has been analysed by FTIR and Atomic force Microscopy [26].

The present work is undertaken:

- to investigate the inhibition efficiency of Hibiscus rosa-sinensis (white) in controlling corrosion of aluminium immersed in an aqueous solution at $\mathrm{pH} 12$ $(\mathrm{NaOH})$, in the absence and presence of $\mathrm{Zn}^{2+}$ using the weight loss method;

- to examine the inhibition efficiency of the flower extract- $\mathrm{Zn}^{2+}$ system;

- to analyze the protective film by Fourier Transform-Infrared (FTIR) spectroscopy;

- to study the potentiodynamic polarization and AC impedance curves of the aqueous flower extract- $\mathrm{Zn}^{2+}$ system. 


\section{Methods and materials}

\section{Preparation of flower extract}

An aqueous extract of white hibiscus flower was prepared by boiling $20 \mathrm{~g}$ of dried flower petals, with distilled water, and making up to $100 \mathrm{~mL}$, after filtering the suspending impurities.

\section{Preparation of specimens}

Commercial aluminium specimens of dimensions $1.0 \times 4.0 \times 0.2 \mathrm{~cm}$, containing $95 \%$ pure aluminium were polished to mirror finish, degreased with trichloroethylene, and used for the weight loss method and for surface examination studies.

\section{Weight loss method}

Three aluminium specimens were immersed in $100 \mathrm{~mL}$ of the solution containing $\mathrm{pH}=12$ and various concentrations of the inhibitor in the absence and presence of $\mathrm{Zn}^{2+}$, at $\mathrm{pH} 12(\mathrm{NaOH})$ for a period of 1 day. The weight of the specimen before and after immersion was determined using Shimadzu balance AY62. Inhibition efficiency (IE) was calculated from the relationship IE $=\left(1-\mathrm{W}_{2} / \mathrm{W}_{1}\right) \mathrm{x}$ 100 , where $\mathrm{W}_{1}=$ corrosion rate in the absence of inhibitor, and $\mathrm{W}_{2}=$ corrosion rate in the presence of the inhibitor.

\section{Surface examination study}

The aluminium specimens were immersed in various test solutions for a period of 1 day. After 1 day, the specimens were taken out and dried. The film formed on the surface of the metal specimens was analysed by surface analysis technique.

\section{FTIR spectra}

These spectra were recorded with the Perkin - Elmer - 1600 spectrophotometer. The FTIR spectrum of the protective film was recorded by carefully removing the film, mixing it with $\mathrm{KBr}$ and making the pellet.

\section{Potentiodynamic polarization study}

Polarization study was carried out in an $\mathrm{H}$ and $\mathrm{CH}$ electrochemical work station Impedance Analyzer Model CHI 660A provided with $i R$ compensation facility, using a three electrode cell assembly. Aluminium was used as working electrode, platinum as counter electrode and saturated calomel electrode (SCE) as reference electrode. After having done $i R$ compensation, polarization study was carried out at a sweep rate of $0.01 \mathrm{~V} / \mathrm{s}$. The corrosion parameters such as Linear Polarization Resistance (LPR), corrosion potential, $\mathrm{E}_{\text {corr }}$, corrosion current, $\mathrm{I}_{\text {corr }}$, and Tafel slopes $\left(b_{a}\right.$ and $\left.b_{c}\right)$, were measured.

\section{Alternating current impedance spectra}

AC impedance spectra were recorded in the same instrument used for polarization study, using the same type of three electrode cell assembly. The real part (Z') and imaginary part (Z') of the cell impedance were measured in ohms 
for various frequencies. The charge transfer resistance $\left(\mathrm{R}_{\mathrm{t}}\right)$ and double layer capacitance $\left(\mathrm{C}_{\mathrm{dl}}\right)$ values were calculated.

\section{Cyclic voltammetry}

Cyclic voltammetry was carried out in an $\mathrm{H}$ and $\mathrm{CH}$ electrochemical work station Impedance Analyzer model CHI 660 provided with iR compensation facility, using a three electrode cell assembly. Aluminium was used as working electrode, platinum as counter electrode, and saturated calomel electrode (SCE) as reference electrode. The graph between (V) vs. current (cyclic voltammetry) was drawn.

\section{Results and discussion}

\section{Analysis of results of weight loss method}

Corrosion rates of aluminium in an aqueous solution at $\mathrm{pH} 12(\mathrm{NaOH})$ in the absence and presence of inhibitors obtained by weight loss method are given in Table 1. The inhibition efficiencies are also given in this table.

It was observed that the white hibiscus extract (WHE) had some efficiency in controlling corrosion of aluminium at $\mathrm{pH} 12$.

Table 1. Corrosion rates of aluminium immersed in $\mathrm{NaOH}$ solution $(\mathrm{pH}=12)$ and the inhibition efficiency obtained by weight loss method.

\begin{tabular}{cccc}
\hline WHE $(\mathbf{m L})$ & $\mathbf{Z n}^{2+}(\mathbf{p p m})$ & $\mathbf{C R}(\mathbf{m d d})$ & $\mathbf{I E}(\boldsymbol{\%})$ \\
\hline 0 & 0 & 117.27 & -- \\
2 & 0 & 89.07 & 24 \\
4 & 0 & 85.55 & 27 \\
6 & 0 & 79.69 & 32 \\
8 & 0 & 93.76 & 40 \\
\hline 0 & 0 & 117.27 & -- \\
0 & 25 & 140.17 & -196 \\
2 & 25 & 77.35 & -100 \\
4 & 25 & 110.17 & -88 \\
6 & 25 & 201.58 & -75 \\
8 & 25 & 205.1 & -72 \\
\hline 0 & 0 & 117.27 & -- \\
0 & 50 & 99.68 & 15 \\
2 & 50 & 90.24 & 23 \\
4 & 50 & 86.73 & 26 \\
6 & 50 & 63.29 & 46 \\
8 & 50 & 2.34 & 98 \\
\hline
\end{tabular}

When $25 \mathrm{ppm}$ of $\mathrm{Zn}^{2+}$ were added to the flower extract, the inhibition efficiency decreased to a great extent. This may be due to the precipitation of the complex formed between $\mathrm{Zn}^{2+}$ and the active principle present in WHE, in the bulk of the solution. The availability of WHE near the metal surface was reduced. Hence a decrease in inhibition efficiency was observed. 
Upon addition of $50 \mathrm{ppm}$ of $\mathrm{Zn}^{2+}$ an improvement in inhibition efficiency was observed. The formulation consisting of $50 \mathrm{ppm}$ of $\mathrm{Zn}^{2+}$ and $8 \mathrm{~mL}$ of the plant extract offered $98 \%$ corrosion inhibition efficiency.

Influence of duration of immersion on the inhibition efficiency of the $\mathrm{Zn}^{2+}$ WHE system

The influence of duration of immersion on the inhibition efficiency of the $\mathrm{Zn}^{2+}$ WHE system is given in Table 2. It was observed that as the duration of immersion increased, the inhibition efficiency decreased. This is due to the fact that as the duration of immersion increased, the protective film formed on the metal surface, probably $\mathrm{Al}^{3+}$ - active principle complex, was broken by the corrosive environment and the film was dissolved.

Table 2. Influence of duration of immersion on the inhibition efficiency of WHE $-\mathrm{Zn}^{2+}$ system.

\begin{tabular}{|l|l|c|c|c|}
\hline \multicolumn{1}{|c|}{ Detail } & & 1 Day & 3 Day & 11 Day \\
\hline Corrosion rate, mdd & Without inhibitor & 117.27 & 65.45 & 111.82 \\
\cline { 2 - 5 } & With inhibitor & 2.34 & 46.36 & 37.27 \\
\hline Inhibition efficiency, \% & & 98 & 29 & 66 \\
\hline \multicolumn{2}{|r}{ Inhibitor system : WHE $8 \mathrm{~mL}+\mathrm{Zn}^{2+} 50 \mathrm{ppm} ; \mathrm{pH}=12(\mathrm{NaOH})}$.
\end{tabular}

\section{Influence of sodium dodecyl sulphate (SDS) on the inhibition efficiency of WHE- $\mathrm{Zn}^{2+}$ system}

When various concentrations of an anionic surfactant, SDS, were added to the inhibitor system, the inhibition efficiency decreased and reached a minimum and then increased (see Table 3). A micelle would have been formed at the minimum efficiency concentration. Afterwards the micelles would have been converted into monomer, which improved the inhibition efficiency. Further research in this direction will lead to development of very interesting new concepts.

Table 3. Influence of sodium dodecyl sulphate (SDS) on the inhibition efficiency of WHE- $\mathrm{Zn}^{2+}$ system.

\begin{tabular}{ccccc}
\hline WHE $(\mathbf{m L})$ & $\mathbf{Z n}^{2+}(\mathbf{p p m})$ & SDS $(\mathbf{p p m})$ & $\mathbf{C R}(\mathbf{m d d})$ & $\mathbf{I E}(\boldsymbol{\%})$ \\
\hline 0 & 0 & 0 & 117.27 & -- \\
8 & 50 & 0 & 2.34 & 98 \\
8 & 50 & 50 & 49.22 & 58 \\
8 & 50 & 100 & 48.05 & 59 \\
8 & 50 & 150 & 65.63 & 44 \\
8 & 50 & 200 & 50.39 & 57 \\
8 & 50 & 250 & 29.30 & 75 \\
\hline \multicolumn{5}{c}{$\mathrm{pH}=12(\mathrm{NaOH}) ;$ duration of immersion = 1 day. }
\end{tabular}

Influence of $N$-cetyl-N,N,N-triemethylammonium bromide (CTAB) on the inhibition efficiency of WHE- $\mathrm{Zn}^{2+}$ systems

It is observed from Table 4 that as the concentration of CTAB increases, the IE increases and then decreases and again increases. A micelle would have been formed at the minimum efficiency concentration. Further research in this direction will lead to development of very interesting new concepts. 
Table 4. Influence of CTAB on the inhibition efficiency of WHE- $\mathrm{Zn}^{2+}$ system.

\begin{tabular}{ccccc}
\hline WHE $(\mathbf{m L})$ & $\mathbf{Z n}^{2+}(\mathbf{p p m})$ & $\mathbf{C T A B}(\mathbf{p p m})$ & $\mathbf{C R}(\mathbf{m d d})$ & IE (\%) \\
\hline 0 & 0 & 0 & 117.27 & -- \\
8 & 50 & 0 & 2.34 & 98 \\
8 & 50 & 50 & 41.04 & 65 \\
8 & 50 & 100 & 34.01 & 71 \\
8 & 50 & 150 & 17.59 & 85 \\
8 & 50 & 200 & 87.95 & 25 \\
8 & 50 & 250 & 75.05 & 36 \\
\hline \multicolumn{5}{c}{}
\end{tabular}

\section{Analysis of polarization curve}

The potentiodynamic polarization curves of aluminium immersed in an aqueous solution at $\mathrm{pH} 12(\mathrm{NaOH})$ are shown in Fig. 1. The corrosion parameters such as corrosion potential $\left(\mathrm{E}_{\mathrm{corr}}\right)$, corrosion current $\left(\mathrm{I}_{\mathrm{corr}}\right)$, Tafel slopes $\left(\mathrm{b}_{\mathrm{a}}, \mathrm{b}_{\mathrm{c}}\right)$, and linear polarization resistance (LPR), are given in Table 5.

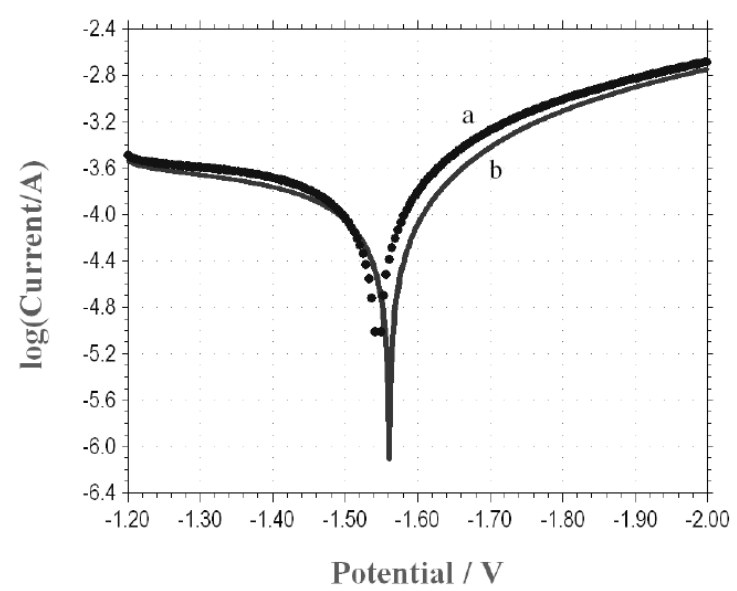

Figure 1. Polarization curves of aluminium immersed in aqueous solution at $\mathrm{pH} 12$ $(\mathrm{NaOH})$. (a) Aqueous solution at $\mathrm{pH} 12$; (b) flower extract $8 \mathrm{~mL}+\mathrm{Zn}^{2+} 50 \mathrm{ppm}(\mathrm{pH}$ 12).

Table 5. Corrosion parameters of aluminium immersed in $\mathrm{NaOH}$ solution $(\mathrm{pH}=12)$ obtained by polarization study.

\begin{tabular}{|c|c|c|c|c|c|c|}
\hline $\begin{array}{l}\text { WHE } \\
(\mathrm{mL})\end{array}$ & $\begin{array}{c}\mathrm{Zn}^{2+} \\
(\mathrm{ppm})\end{array}$ & $\begin{array}{c}\mathbf{E}_{\text {corr }}(\mathbf{m V} \text { vs } \\
\text { SCE })\end{array}$ & $\begin{array}{c}\mathbf{b}_{\mathbf{c}} \\
(\mathbf{m V})\end{array}$ & $\begin{array}{c}\mathbf{b}_{\mathbf{a}} \\
(\mathbf{m V})\end{array}$ & $\begin{array}{c}\text { LPR } \\
\left(\mathrm{ohm} \mathbf{c m}^{2}\right)\end{array}$ & $I_{\text {corr }}\left(\mathbf{A} / \mathbf{c m}^{2}\right)$ \\
\hline 0 & 0 & -1545 & 204 & 402 & $4.155 \times 10^{2}$ & $1.412 \times 10^{-4}$ \\
\hline 8 & 50 & -1561 & 192 & 365 & $5.487 \times 10^{2}$ & $0.9953 \times 10^{-4}$ \\
\hline
\end{tabular}

When aluminium is immersed in a $\mathrm{pH} 12$ aqueous solution $(\mathrm{NaOH})$, the corrosion potential is $-1545 \mathrm{mV}$ vs. SCE. When the inhibitors are added $(8 \mathrm{~mL}$ of extract WHE and $50 \mathrm{ppm}$ of $\mathrm{Zn}^{2+}$ ), the corrosion potential shifts to cathodic side $\left(-1561 \mathrm{mV}\right.$ vs. SCE). Further LPR value increases from $4.155 \times 10^{2}$ to $5.487 \times 10^{2}$ and corrosion current decreases from $1.412 \times 10^{-4}$ to $0.9953 \times 10^{-4}$ 
$\mathrm{A} / \mathrm{cm}^{2}$. These results suggest that a protective film is formed on the metal surface. This protects the metal from corrosion.

\section{Analysis of AC impedance spectra}

The AC impedance spectra of aluminium immersed in an aqueous solution at $\mathrm{pH}$ $12(\mathrm{NaOH})$ are shown in Fig. 2. The AC impedance parameters such as charge transfer resistance $\left(\mathrm{R}_{\mathrm{t}}\right)$, double layer capacitance $\left(\mathrm{C}_{\mathrm{dl}}\right)$ [derived from Nyquist plots (Fig.2a and b)], and impedance, $\log (\mathrm{z} / \mathrm{ohm})$, values derived from Bode plots (Fig.2c and d), are given in Table 6.

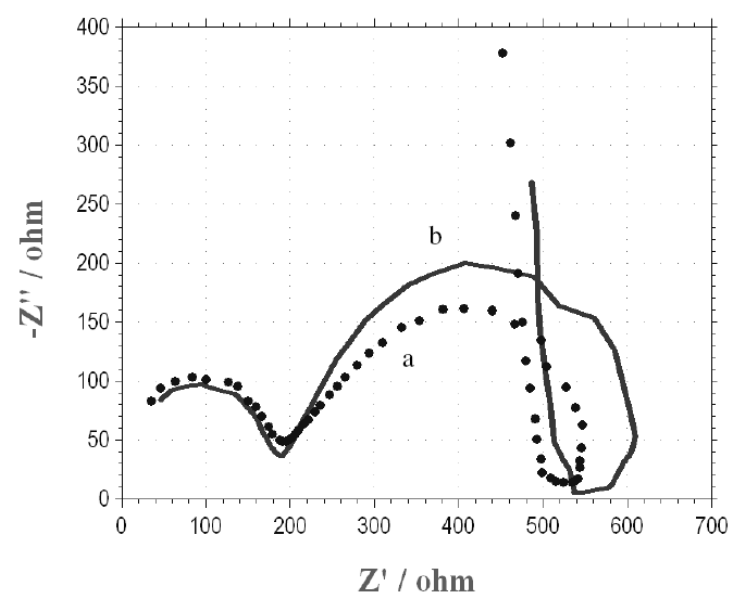

Figure 2 (a and b). AC impedance spectra of aluminium immersed in aqueous solution at $\mathrm{pH} 12(\mathrm{NaOH})$. Nyquist plots: (a) aqueous solution at $\mathrm{pH} \mathrm{12;} \mathrm{(b)} \mathrm{flower} \mathrm{extract} 8 \mathrm{~mL}$ $+\mathrm{Zn}^{2+} 50 \mathrm{ppm}(\mathrm{pH} 12)$.
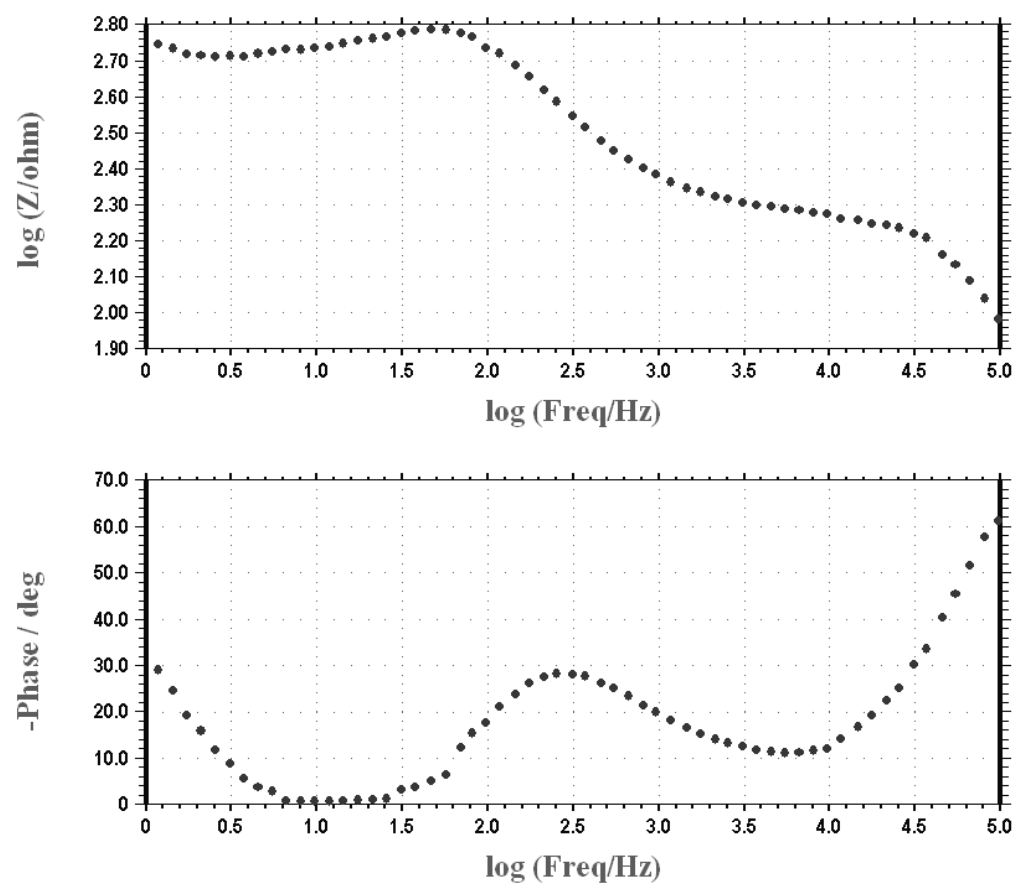

Figure 2c. AC impedance spectra of aluminium immersed in aqueous solution at $\mathrm{pH} 12$ $(\mathrm{NaOH})$. Bode plots: (c) aqueous solution at $\mathrm{pH} 12$. 

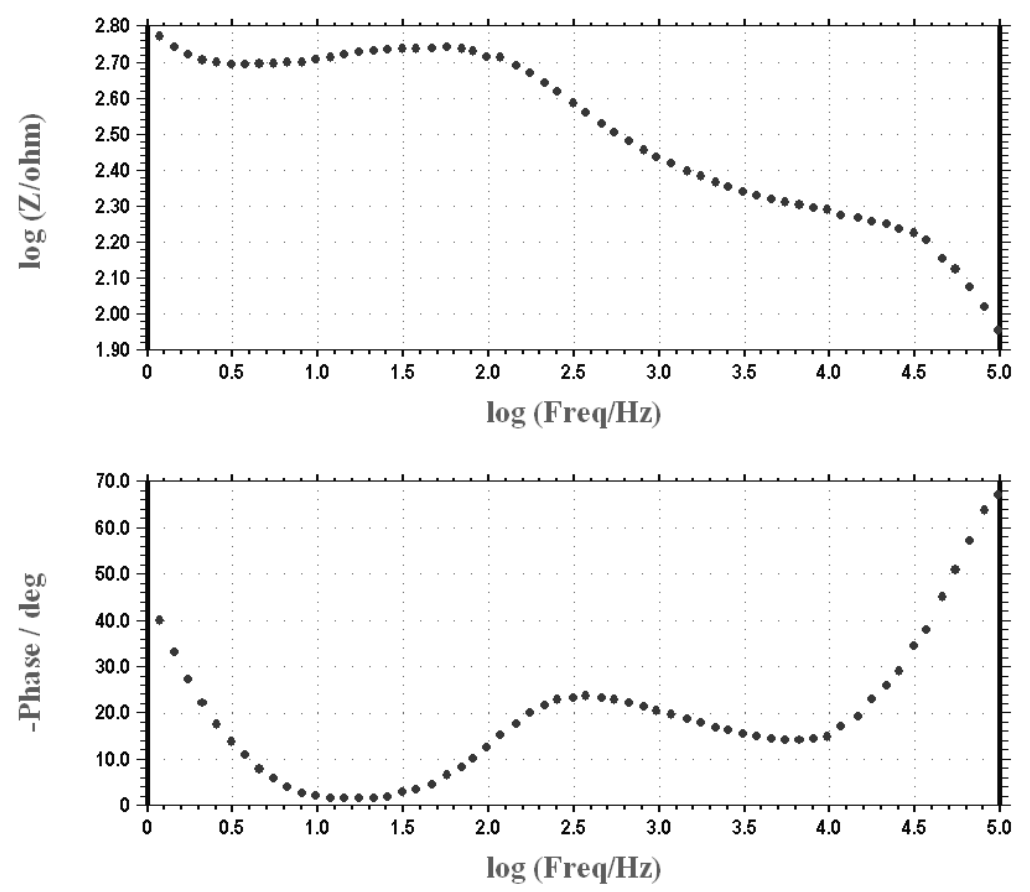

Figure 2d. AC impedance spectra of aluminium immersed in aqueous solution at $\mathrm{pH}$ $12(\mathrm{NaOH})$. Bode plots: (d) flower extract $8 \mathrm{~mL}+\mathrm{Zn}^{2+} 50 \mathrm{ppm}(\mathrm{pH} \mathrm{12})$.

Table 6. AC impedance parameters of aluminium immersed in $\mathrm{NaOH}$ solution $(\mathrm{pH}=$ 12) obtained by AC impedance spectra.

\begin{tabular}{|c|c|c|c|c|c|c|}
\hline \multirow{2}{*}{$\begin{array}{l}\text { WHE } \\
(\mathbf{m L})\end{array}$} & \multirow[t]{2}{*}{$\begin{array}{c}\mathrm{Zn}^{2+} \\
(\mathbf{p p m})\end{array}$} & \multicolumn{2}{|c|}{$\underset{\left(\mathbf{o h m} \mathbf{~ c m}^{2}\right)}{\mathbf{R}_{\mathrm{t}}}$} & \multicolumn{2}{|c|}{$\begin{array}{c}\mathrm{C}_{\mathrm{dl}} \\
\left(\mu \mathrm{F} / \mathrm{cm}^{2}\right)\end{array}$} & \multirow{2}{*}{$\begin{array}{l}\text { Impedance } \\
\log (\mathrm{z} / \mathrm{ohm})\end{array}$} \\
\hline & & $\mathbf{R}_{\mathrm{t} 1}$ & $\mathbf{R}_{\mathrm{t} 2}$ & $\mathrm{C}_{\mathrm{dl1}}$ & $\mathbf{C}_{\mathrm{d} 12}$ & \\
\hline 0 & 0 & 159.22 & 353.2 & $1.8286 \times 10^{-8}$ & $2.098 \times 10^{-6}$ & 2.76 \\
\hline 8 & 50 & 144.31 & 420.7 & $2.0171 \times 10^{-8}$ & $2.1530 \times 10^{-6}$ & 2.78 \\
\hline
\end{tabular}

When $\mathrm{Al}$ was immersed in $\mathrm{NaOH}$ solution at $\mathrm{pH} 12$, two semicircles were observed. The one at high frequency region corresponds to corrosion process; the other at low frequency region corresponds to protective nature of the film formed on the metal surface. It was observed that there was increase in charge transfer resistance and decrease in double layer capacitance values. These observations suggested that, a protective film was formed on the metal surface in the presence of inhibitors, namely, $50 \mathrm{ppm}$ of $\mathrm{Zn}^{2+}$ and $8 \mathrm{~mL}$ of flower extract. This fact was further confirmed by the evidence that, there was increase in the value of impedance, $\log (\mathrm{z} / \mathrm{ohm})$, when inhibitors were added.

\section{Analysis of cyclic voltammograms}

The cyclic voltammogram of aluminium immersed in an aqueous solution at $\mathrm{pH}$ 12 is shown in Fig. 3a. The $\mathrm{E}_{\mathrm{p}}$ is found to be $0.589 \mathrm{~V}$ and the $\mathrm{iP}$ is found to be $7.915 \times 10^{-6} \mathrm{~A} / \mathrm{cm}^{2}$. The $\mathrm{Ah}$ value is $2.9720 \times 10^{-6} \mathrm{C}$. These values correspond to corrosion of aluminium at $\mathrm{pH} 12$. The potential $0.589 \mathrm{~V}$ may be due to formation of $\mathrm{Al}^{3+}$ at $\mathrm{pH}$ 12. When $\mathrm{Al}$ is immersed in the inhibitor solution (Fig. $3 \mathrm{~b}$ ), the peak has disappeared, indicating protective nature of the film formed on the metal surface, in the presence of inhibitor system. Further the bulging out 
appearance of the cyclic voltammogram suggests the capacitance behaviour of the film formed on the metal surface. Corrosion of metal by release of electron is prevented.
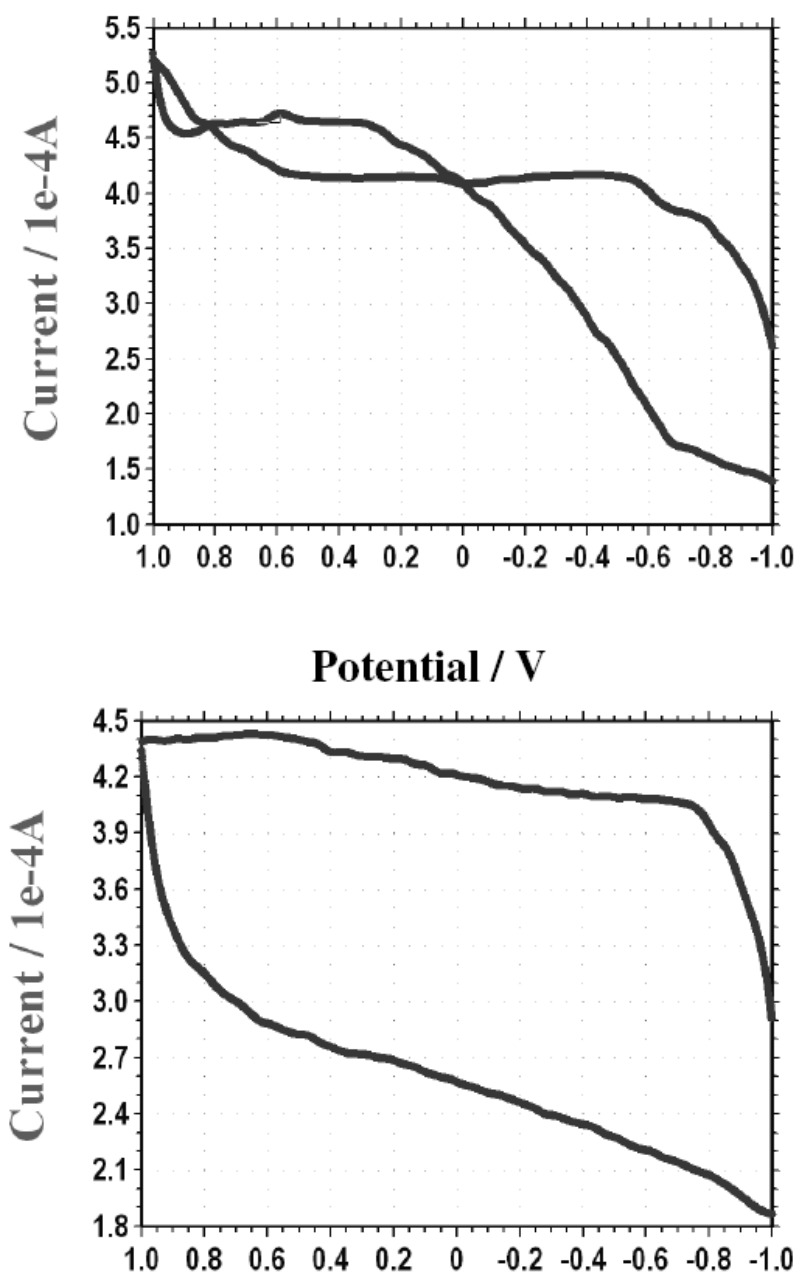

a)

Potential / V

b)

Figure 3. Cyclic voltammograms of aluminium immersed in aqueous solution at $\mathrm{pH} 12$ $(\mathrm{NaOH})$. (a) Aqueous solution at $\mathrm{pH} 12$; (b) (b) Flower extract $8 \mathrm{~mL}+\mathrm{Zn}^{2+} 50 \mathrm{ppm}$ (pH 12).

\section{Analysis of FTIR spectra}

A few drops of an aqueous extract of flower were placed on a glass plate and evaporated to dryness. A solid was obtained. Its FTIR spectrum $(\mathrm{KBr})$ is shown in Fig.4. The peak at $3439 \mathrm{~cm}^{-1}$ corresponds to $-\mathrm{OH}$ stretching frequency; the peak at $1638 \mathrm{~cm}^{-1}$ corresponds to $-\mathrm{C}=\mathrm{O}$ stretching frequency; the peak at 1122 $\mathrm{cm}^{-1}$ is due to ring oxygen atom. Thus the active principle in aqueous extract of the flower, quercetin-3-O-glucoside (Fig. 5) [26] is confirmed by FTIR.

A few drops of freshly prepared aluminium sulphate solution were mixed with the aqueous flower extract; aluminium - flower extract complex was formed. It was evaporated to dryness, and the FTIR spectrum (KBr) was recorded (Fig. 4b). The $-\mathrm{OH}$ stretching frequency has shifted from 3439 to $3443 \mathrm{~cm}^{-1}$; the $-\mathrm{C}=\mathrm{O}$ stretching frequency has shifted from 1638 to $1640 \mathrm{~cm}^{-1}$, and the ring oxygen 
atom - frequency has shifted from 1122 to $1120 \mathrm{~cm}^{-1}$. These evidences indicate that during the formation of aluminium complex, there is coordination between $\mathrm{Al}^{3+}$ and the oxygen atoms of $-\mathrm{OH}$ group, $-\mathrm{C}=\mathrm{O}$ group and ring oxygen atom.
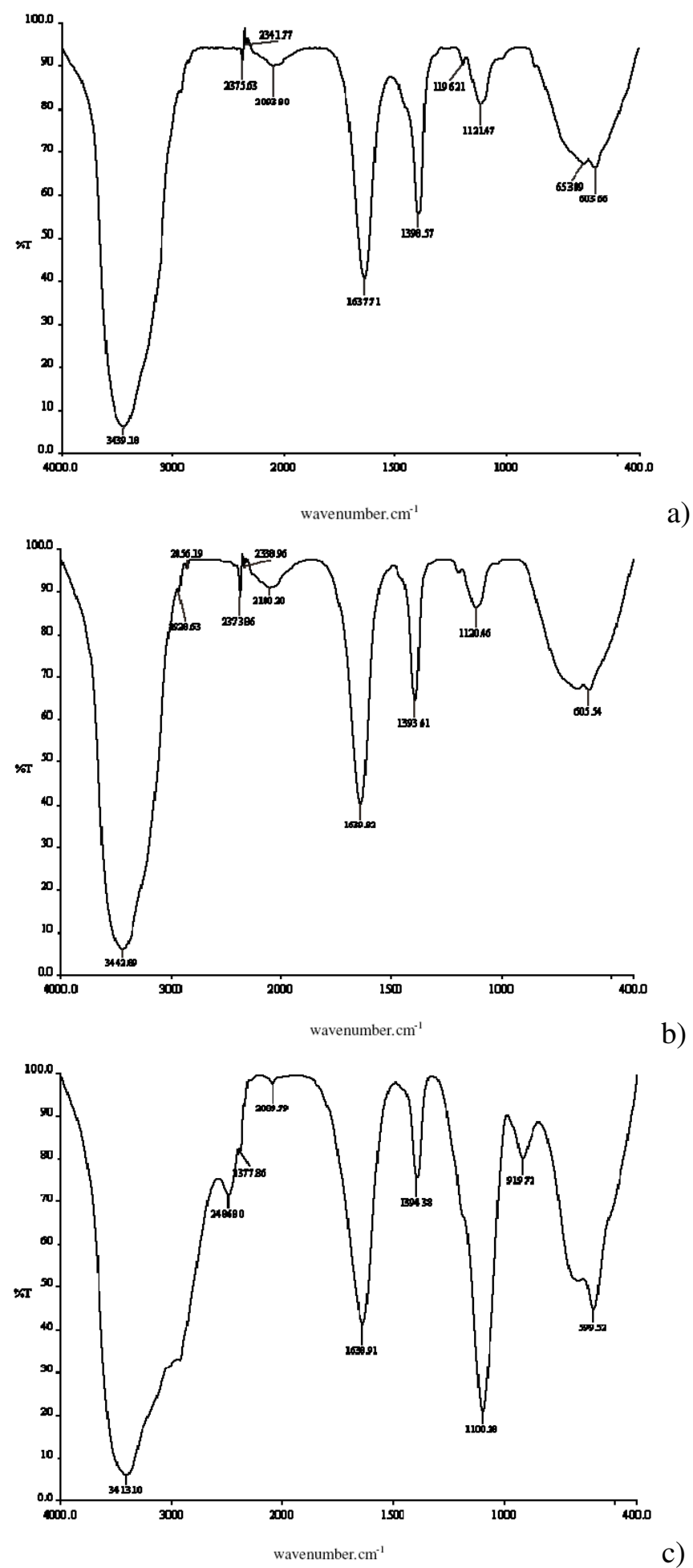

Figure 4. FTIR spectra (KBr). (a) Flower extract dried to solid mass; (b) Flower extract $\mathrm{Al}^{3+}$ complex; (c) Film formed on aluminium metal surface after immersion in the aqueous solution ( $\mathrm{pH}$ 12) containing $8 \mathrm{~mL}$ of flower extract $+50 \mathrm{ppm}$ of $\mathrm{Zn}^{2+}$. 
The FTIR spectrum of the protective film formed on the surface of the metal after immersion in the solution containing $8 \mathrm{~mL}$ of flower extract and $50 \mathrm{ppm}$ of $\mathrm{Zn}^{2+}$, is shown in Fig. 4c.

The $-\mathrm{OH}$ stretching frequency has shifted from 3439 to $3413 \mathrm{~cm}^{-1}$; the $-\mathrm{C}=\mathrm{O}$ stretching frequency has shifted from 1638 to $1640 \mathrm{~cm}^{-1}$; and ring oxygen atom stretching frequency has shifted from 1122 to $1100 \mathrm{~cm}^{-1}$.

This confirms the presence of $\mathrm{Al}^{3+}$ - flower extract complex on the metal surface. $\mathrm{Al}^{3+}$ has coordinated with the $\mathrm{O}$-atom of the $-\mathrm{OH}$ group, $-\mathrm{C}=\mathrm{O}$ group and the ring oxygen atom. Similar observation has been made by Anuradha et al., who reported the formation of $\mathrm{Fe}^{2+}$ - flower extract complex, while studying the inhibition of corrosion of carbon steel by the flower extract [26].

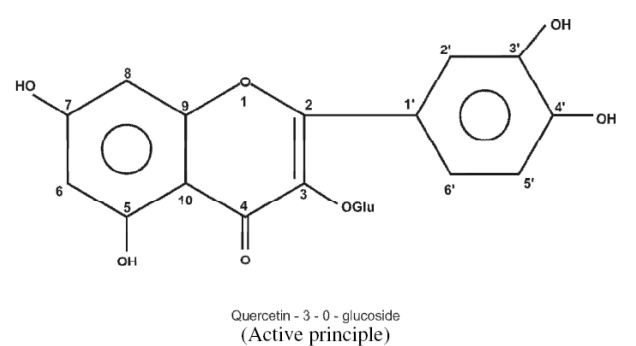

Figure 5. Quercetin -3-0-glucoside.

\section{Conclusions}

The inhibition efficiency (IE) of an aqueous extract of Hibiscus rosa-sinensis (white) in controlling corrosion of aluminium at $\mathrm{pH} 12$ has been evaluated by

- weight loss method in the absence and presence of $\mathrm{Zn}^{2+}$;

- the formulation consisting of $8 \mathrm{~mL}$ flower extract (FE) and $50 \mathrm{ppm}$ of $\mathrm{Zn}^{2+}$ had 98\% inhibition efficiency;

- polarization study revealed that this formulation functioned as cathodic inhibitor;

- AC impedance spectra revealed the presence of a protective film formed on the metal surface;

- FTIR spectra revealed that the protective film consisted of a complex formed between the active principle of the flower extract and $\mathrm{Al}^{3+}$.

\section{Acknowledgement}

The authors are thankful to their respective managements, St. Joseph's Research and Community Development Trust, Dindigul-3 and University Grants Commission, India, for their help and encouragement.

\section{References}

1. M.A. Quraishi, M.Z.A. Rafiquee, S. Khan, N. Saxna, J. Appl. Electrochem. 37 (2007) 1153.

2. $\quad$ P. Arora, S. Kumar, M.K. Sharma, S.P. Mathur, E-J. Chem. 4 (2007) 450.

3. S.A. Umoren, O. Ogbobe, P.C. Okafor, E.E. Ebenso, J. Polym. Sci. 105 (2007) 3363.

4. O.K. Abiola, N.C. Oforka, E.E. Ebenso, N.M. Nwinuka, Anti-Corrosion Methods Mater. 54 (2007) 219. 
5. E.E. Oguzie, Corros. Sci. 49 (2007) 1597.

6. S.A. Umoren, E.E. Ebenso, P.C. Okafor, U.J. Ekpe, O. Ogbobe, J. Appl. Polym. Sci. 103 (2007) 2810.

7. E.E. Oguzie, G.N. Onuoha, E.N. Ejike, Pigment and Resin Technol. 30 (2007) 44.

8. E.E. Oguzie, B.N. Okolue, C.E. Ogukwe, C. Unaegbu, Mater. Let. 60 (2006) 3376.

9. S. Rajendran, M. Manivannan, J.W. Sahayaraj, J.A. Selvi, J. Sathiyabama, A.J. Amalraj, N. Palaniswamy, Trans. SAEST 41 (2006) 63.

10. S. Rajendran, S. Muthulakshmi, R. Rajeswari, A. Vijitha, J. Electrochem. Soc., India 54 (2005) 50.

11. P.M. Barkhudarov, P.B. Shah, E.B. Watkis, D.A. Doshi, C.J. Brinker, J. Majewski, Corros. Sci. 50 (2008) 897.

12. K. Wapner, M. Stratmann, G. Grundmaier, Int. J. Adhesion Adhesives 28 (2008) 59.

13. E. Juzeliunas, R. Ramanauskas, A. Lugauskas, K. Leinartas, M. Samuleviciene, A. Sudavicius, R. Juskenas, Corros. Sci. 49 (2007) 4098.

14. A.K. Mishra, R. Balasubramaniam, Mater. Chem. Phys. 103 (2007) 385.

15. P.B. Srinivasan, W. Dietzel, R. Zettler, J.F. dos Santos, V. Sivan, Corros. Eng. Sci. Techn. 42 (2007) 161.

16. B.D. Chambers, S.R. Taylor, Corros. Sci. 49 (2007) 1597.

17. P. Karlsson, A.E.C. Palmquist, K. Holmberg, Adv. Colloid Interf. Sci. 128130 (2007) 121.

18. A.J. Coleman, H.N. McMurray, G. Williams, A. Afseth, G. Seamans, Mater. Sci. Forum 519-521 (PART 1) (2006) 629.

19. S. Rajendran, V. Ganga Sri, J. Arockia Selvi and A. John Amalraj, Bulletin of Electrochemistry 21(8) (2005) 367-377.

20. S. Rajendran, S. Shanmugapriya, T. Rajalakshmi, A.J. Amalraj, Corrosion 61 (2005) 685.

21. N. Anthony, E. Malarvizhi, P. Maheswari, S. Rajendran, N. Palaniswamy, Ind. J. Chem. Techn. 11 (2004) 346.

22. S. Rajendran, A.J. Amalraj, M.J. Joice, N. Anthony, D.C. Trivedi, M. Sundaravadivelu, Corros. Rev. 22 (2204) 233.

23. H.H. Rehan, Materialwissenschaft und Werkstoffechnik 34 (2003) 232.

24. L. Priya, A. Chitra, S. Rajendran, K. Anuradha, Surf. Eng. 21 (2005) 229.

25. T. Jain, R. Chowdhary, S.P. Mathur, Mater. Corros. 57 (2006) 422.

26. K. Anuradha, R. Vimala, B. Narayanasamy, J.A. Selvi, S. Rajendran, Chem. Eng. Comm. 195 (2008) 352. 